НЗВЕСТИЯ АКАДЕМИИ НАУК ЭСТОНСКОИ ССР. ТОМ 26 ХИМИЯ * ГЕОЛОГИЯ. 1977, № 1

\title{
STRUCTURE OF TOLYPELEPIS FROM THE BALTIC UPPER SILURIAN
}

In the present paper some new data on Tolypelepis, the oldest known cyathaspid is given. Tolypelepis has been reported from the Silurian and Early Devonian of different regions of the northern hemisphere: the East Baltic, North Germany (erratics), England, Canada and Timan (Denison, 1964). Most of the occurrences come from the Late Silurian, those of the Early Silurian and Early Devonian are rare. From all the occurrences, only one species, Tolypelepis undulata Pander, Upper Silurian, Downtonian, Ohesaare Stage of Estonia, has been described so far. The new finds of this remarkable

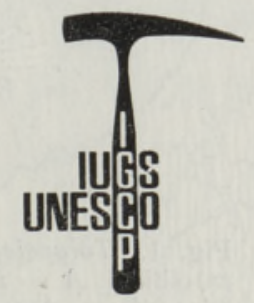

Проект «Экостратиграфия» form come from the type locality, Ohesaare, Saaremaa (Oesel) Island, and from some borings of Estonia and Lithuania.

The specimens with indexes $\mathrm{Pi}$ are preserved at the Geology Museum of the Estonian Academy of Sciences.

I am much indebted to colleague V. Karatajute-Talimaa, Vilnius, for the specimen of Tolypelepis (25-023) from Lithuania.

\section{Tolypelepis Pander, 1856}

\section{Type-species. Tolypelepis undulatus Pander, 1856.}

D i a g nosis. The dorsal and ventral shields are broad. The dorsal shield lacks a median rostral process, and has shallow orbital notches, The posterior margins of both shields are strongly convex and zigzag. The epitega of dorsal shield are distinctly separated by ridge pattern and sometimes by apparent sutures. The postrostral field with pineal tessera is distinguished from the central epitegum. On the central epitegum of dorsal shield and locally on the branchial plate, scale-like tesserae occur. The ventral shield may be occupied by tesserae entirely or partly. On tesserae, the narrow short dentine ridges are arranged around a coarser higher central ridge. The lateral line canals occur as short segments. (Diagnosis by Denison 1964 with supplements).

O c c u r r e n ce. Lower Silurian, Lower Wenlockian of Canada; Upper Silurian, Downtonian of the East Baltic, North Germany (erratics), England; Early Devonian of Timan.

\section{Tolypelepis undulata Pander, 1856}

Ty pe. Shield fragment figured by Pander (1856, Pl. 6, Fig. 24); Saaremaa Island, Ohesaare Cliff, Downtonian, Ohesaare Stage. 

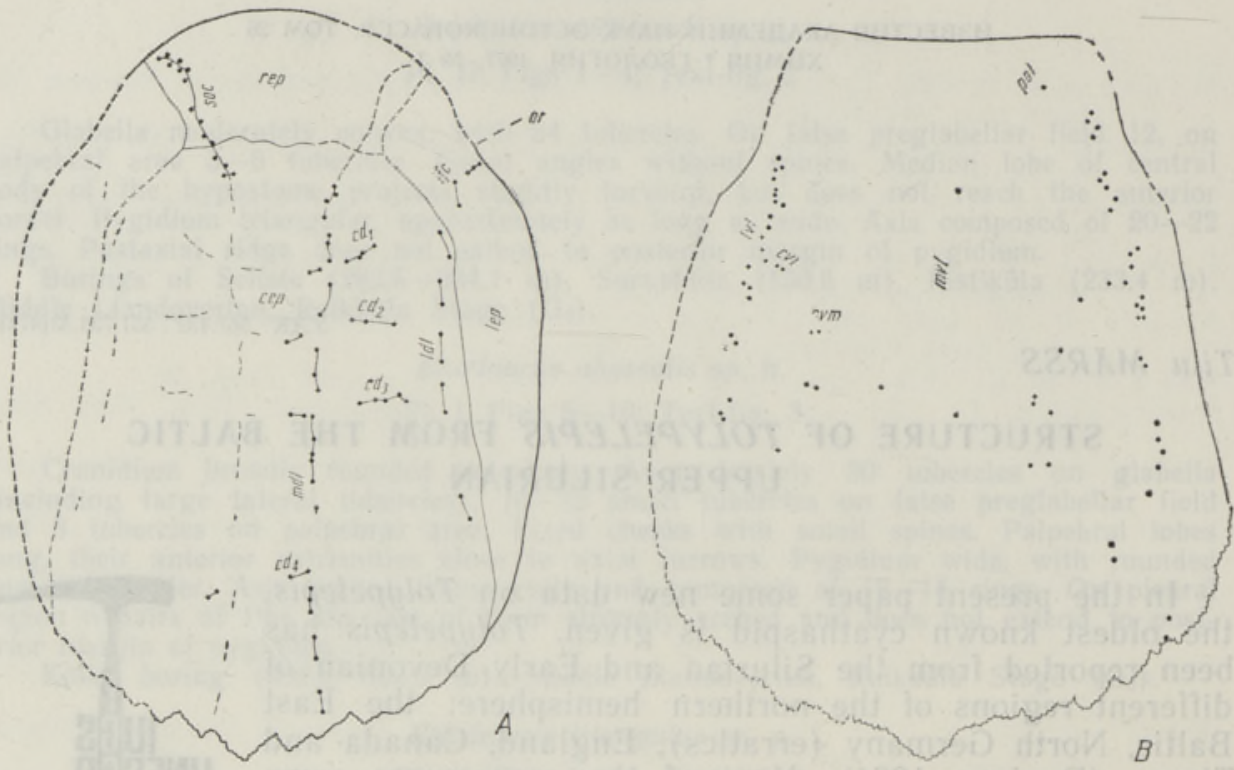

Fig. 1. Tolypelepis undulata, restoration of shields; $A-$ dorsal shield; $B$ - ventral shield. $A$ - after Pi 5000, Pi 5002, Pi 5003; B - after Pi 5004, Pi 5005, 25-023, X2 $c d_{1}-c d_{4}$ - dorsal transverse commissures; cep - central epitegum; cvl, cvm - pores of lateral and medial ventral transverse commissures; if $c$ - infraorbital canal; ldl. $m d l$ - lateral and medial dorsal canal; lep - lateral epitegum; $l v l, m v l$ - pores of lateral and medial ventral sensory canal; or - orbit; pol - pores of postoral sensory canal; rep - rostral epitegum; soc - supraorbital canal.

$\mathrm{D}$ i a $\mathrm{g} \mathrm{n}$ o $\mathrm{s}$ i s. The length of the dorsal shield is $32-38 \mathrm{~mm}$, maximum width $23 \mathrm{~mm}$, width ratio $0.67-0.70$, pineal ratio $0.24-0.25$ and orbital ratio $0.14-0.18$. The thickness of the shield is $0.5-0.7 \mathrm{~mm}$. The length of the ventral shield is $36 \mathrm{~mm}$. On the dorsal shield there are 4 dentine ridges per $\mathrm{mm}$ on the average; the largest are about 2 per $\mathrm{mm}$ on the central epitegum, and the smallest on the lateral epitega are about 8 per $\mathrm{mm}$. On the central part of the ventral shield there are 3-4 dentine ridges per $\mathrm{mm}$ and on the lateral part $4-5$ per $\mathrm{mm}$.

Occurrence. Upper Silurian, Downtonian, Kaugatuma Stage $\left(\mathrm{K}_{3} \mathrm{~b}\right)$ in Kaugatuma and Ohesaare borings, Ohesaare Stage in Ohesaare Cliff; Upper Silurian in Sõrve (514) and Ruhnu borings (all in Estonia); Minija + Jura Beds in Butkunai boring, Lihtuania; Upper Silurian erratics of North Germany (Gross, 1961).

Description. The dorsal shield, the almost complete ventral shield, the branchial and suborbital plates and scales are considered in the present paper.

The description of the dorsal shield is largely based on two specimens figured by Rohon (1893, Pl. I, Fig. 45), Kiaer (1932, Pl. X) and Stensiö (1958, Fig. $169 A, B ; 1964$, Fig. $71 A, B$ ). Some large fragments that have been found later gave a possibility to reconstruct one more dorsal shield (Fig. 1A). The dorsal shield of Tolypelepis undulata is elliptical (Fig. $1 A$ ) and dorsally arched. Its anterior border is smoothly convex. The median rostral process is absent. Preorbital processes are weakly developed, with an indistinct maxillary brim in between. The posterior margin of the dorsal shield is zigzag, strongly convex, with a median point formed by a large tessera (Fig. $2 C$; Plate, Fig. 4). The dorsal shield 

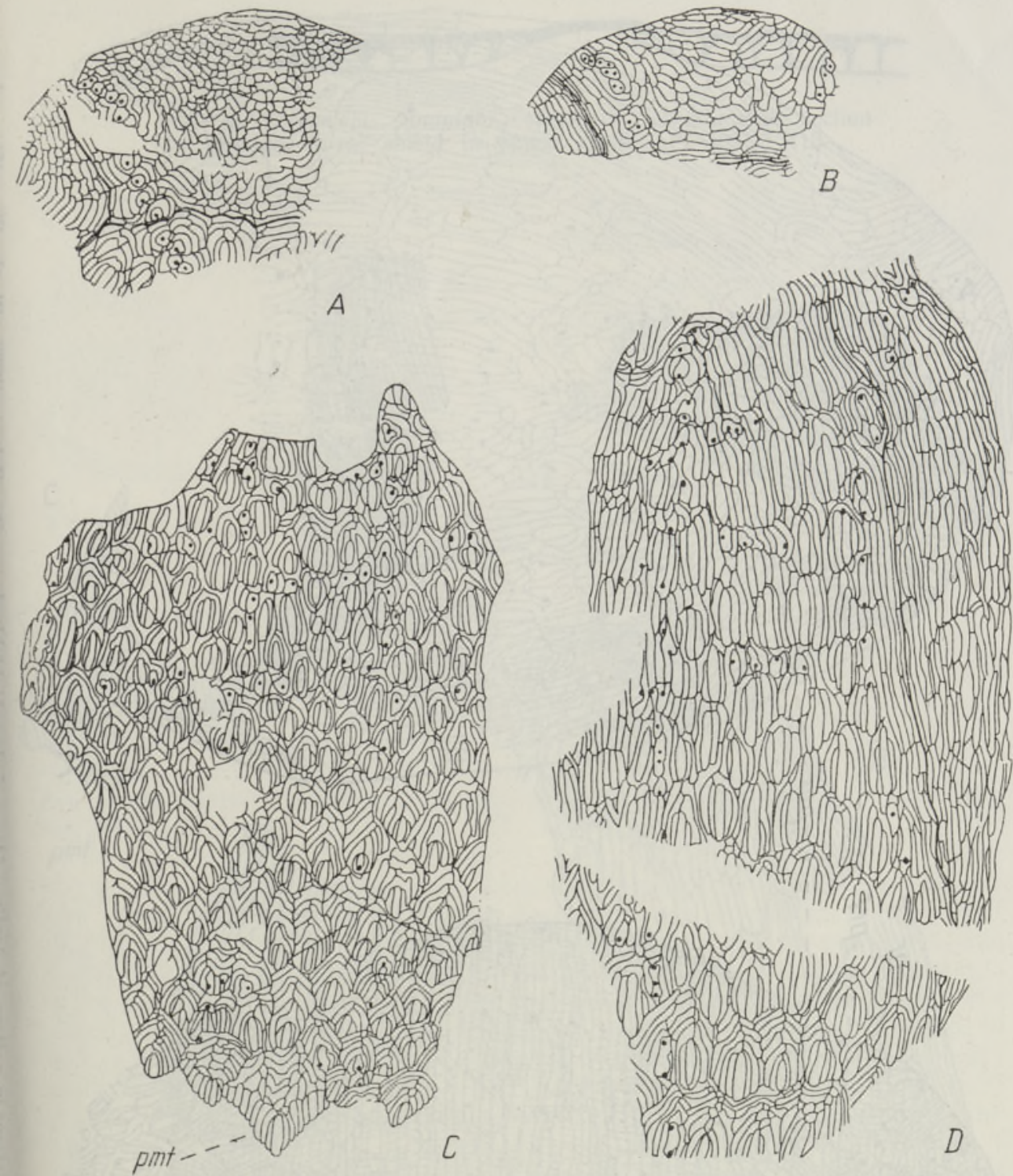

Fig. 2. Tolypelepis undulata, variations in pattern of dentine ridges. $A, B$ - rostral epitega; $A-\mathrm{Pi} 5000 ; B-\mathrm{Pi} 5001 ; C-$ central epitegum, $\mathrm{Pi} 5002 ; D-$ right side of central epitegum and right lateral epitegum, $\mathrm{Pi} 5003, \times 4$. pmt - postero-median tessera.

is clearly divisible into rostral, central and lateral epitega by sutures and by pattern of dentine ridges. The rostral epitegum (Figs $2 A, B, 3$; Plate, Figs 1,2$)$ has relatively long and partly transverse dentine ridges or denticles. On the central epitegum the elliptical ridge pattern is formed by tesserae or short dentine ridges (Figs $2 C, D, 3$; Plate, Figs 3,4 ). The postrostral field (Fig. 3) is distinct from the central epitegum. The tesserae of the postrostral field may be arranged transversally or diagonally. Anteroposteriorly elongated pineal macula is clearly indicated by an oval ridge pattern. The shield on the pineal macula is very thin, $0.15 \mathrm{~mm}$ (Fig. 4) 
18

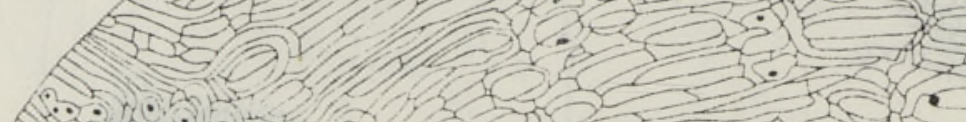

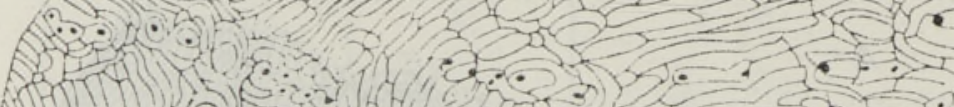

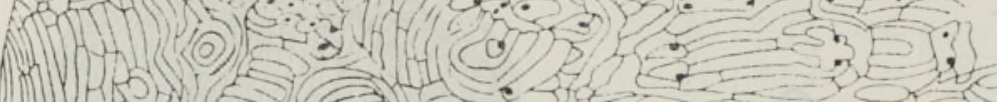

\section{- $m$ )}

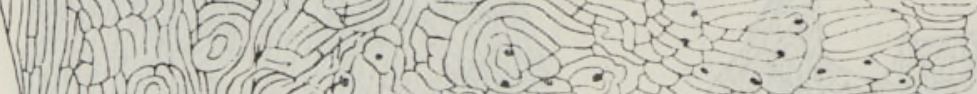

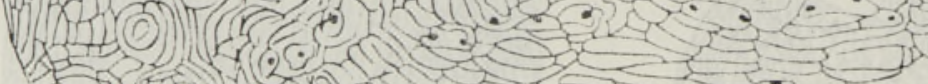

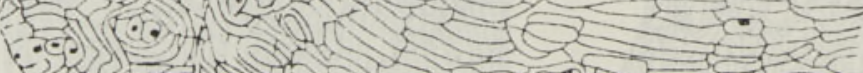

s) $=42$. तै.

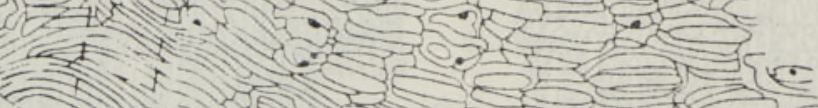

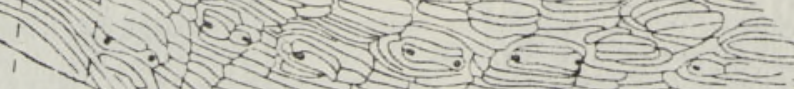

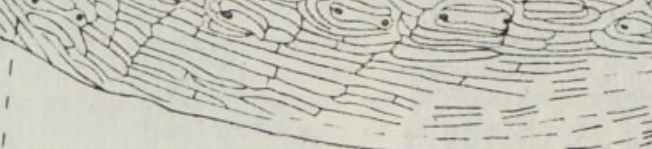

太

斿

方 1

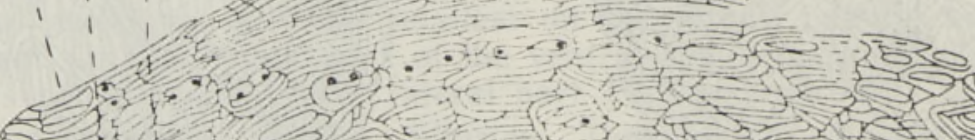

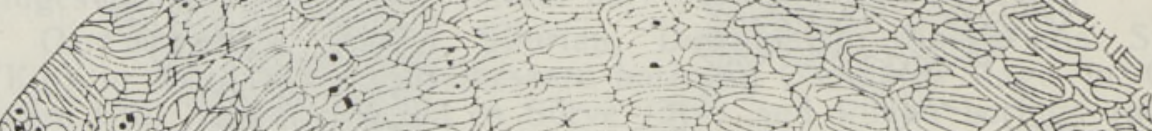

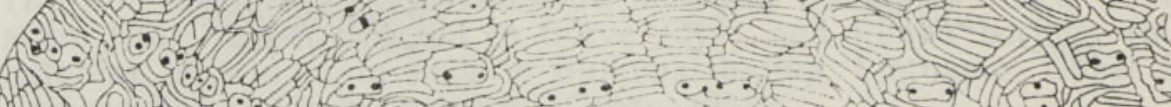

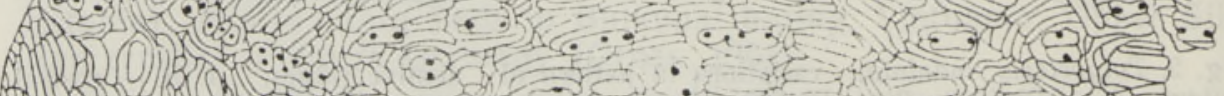

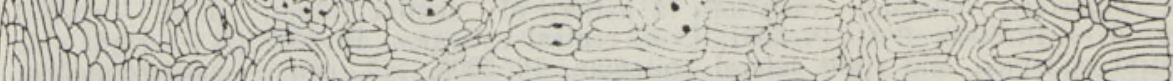

כ)

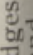




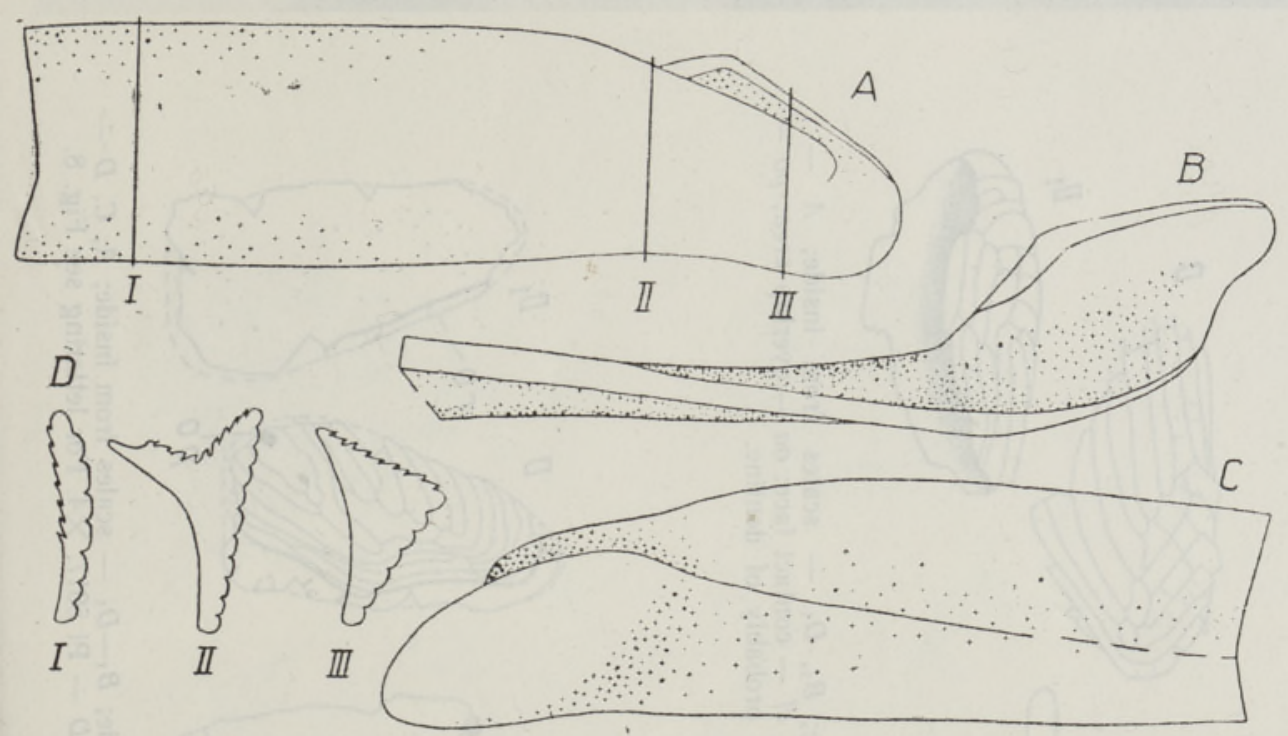

Fig. 7. Tolypelepis undulata, restoration of medial and posterior parts of left branchial plate. $A-$ from outside; $B-$ from dorsal side; $C-$ from inside; $D_{\mathrm{I}-\mathrm{III}}-$ cross-sections of plate, $\times 6$.

In the posterior part of the upper margin of the plate there is an overlap area without ornamentation. On the upper part of the inner side branchial plate there are 9 transparent ribs per $\mathrm{mm}$. They seem to be of dentine. The lower margin of the branchial plate shows a wide overlap area on the inside.

The right suborbital plate is small, only $4 \mathrm{~mm}$ long (Fig. 6C). Its anterior end is narrow and strongly curved inwards; the plate becomes wider posteriorly. The central part is flat, the upper part is curved inward posteriorly. The anterior and posterior portions of the lower margin form a right angle. The upper margin is embayed by a shallow orbital notch. On the narrow frontal part of the plate there is an overlap area. A single, probably dentine, rib runs parallelly to the visceral edge of the orbital notch. The outer surface of the plate is covered with dentine ridges placed mostly parallelly to the orbital notch. In the posterior part they are situated vertically. The upper ridges are finer $(5$ per $\mathrm{mm})$ than the lower ones (4 per $\mathrm{mm})$.

By dissolving the rock samples, many scales and a detached plate have been obtained. The plate (Fig. 6D, $D_{1}$ ) resembles that of Anglaspis heintzi, figured by Heintz (1962, Fig. 7, L. P.) and it is here provisionally identified as a lateral plate. It is relatively flat, large ( $4 \mathrm{~mm}$ broad) and asymmetrical; its probable anterior margin is convex, with 6 dentine ridges running parallel to the margin. The probable posterior edge of the plate is crushed, the lateral margins that carry dentine ridges are convex and folded downwards. They are finer than those on the outer surface. The dentine ridges on the outside have an almost longitudinal course. There are no traces of overlap areas.

The anteriorly situated median scales (Fig. 8) are symmetrical, relatively broad and flat (Fig. $8 A$ ). In the rear they become narrow and strongly curved (Fig. $8 D$ ). There is a coarse and long central ridge along the midline, there are narrower and shorter ridges around it. The dorso-Iateral scales (Fig. 9) are high and relatively short, flat or slightly 


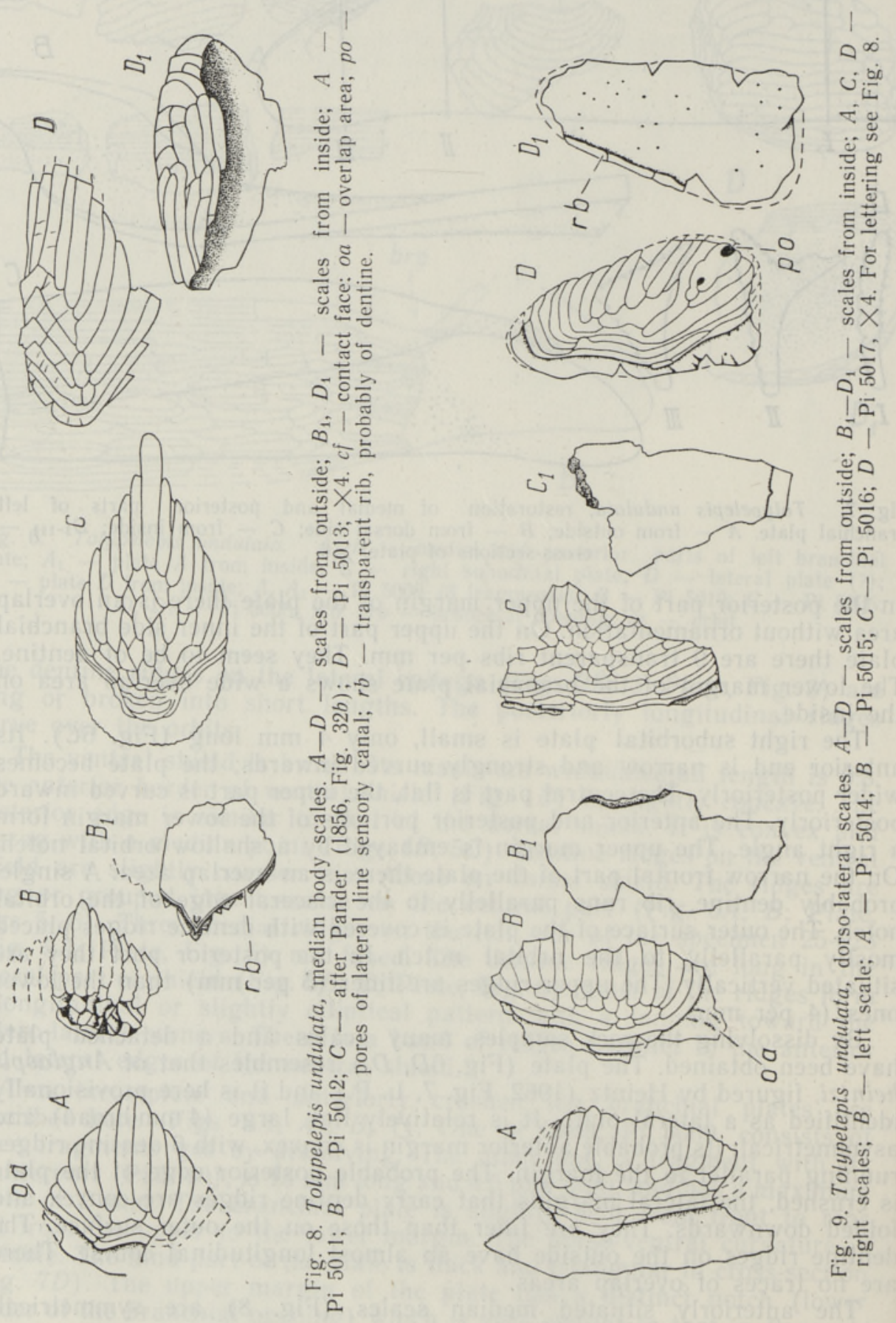




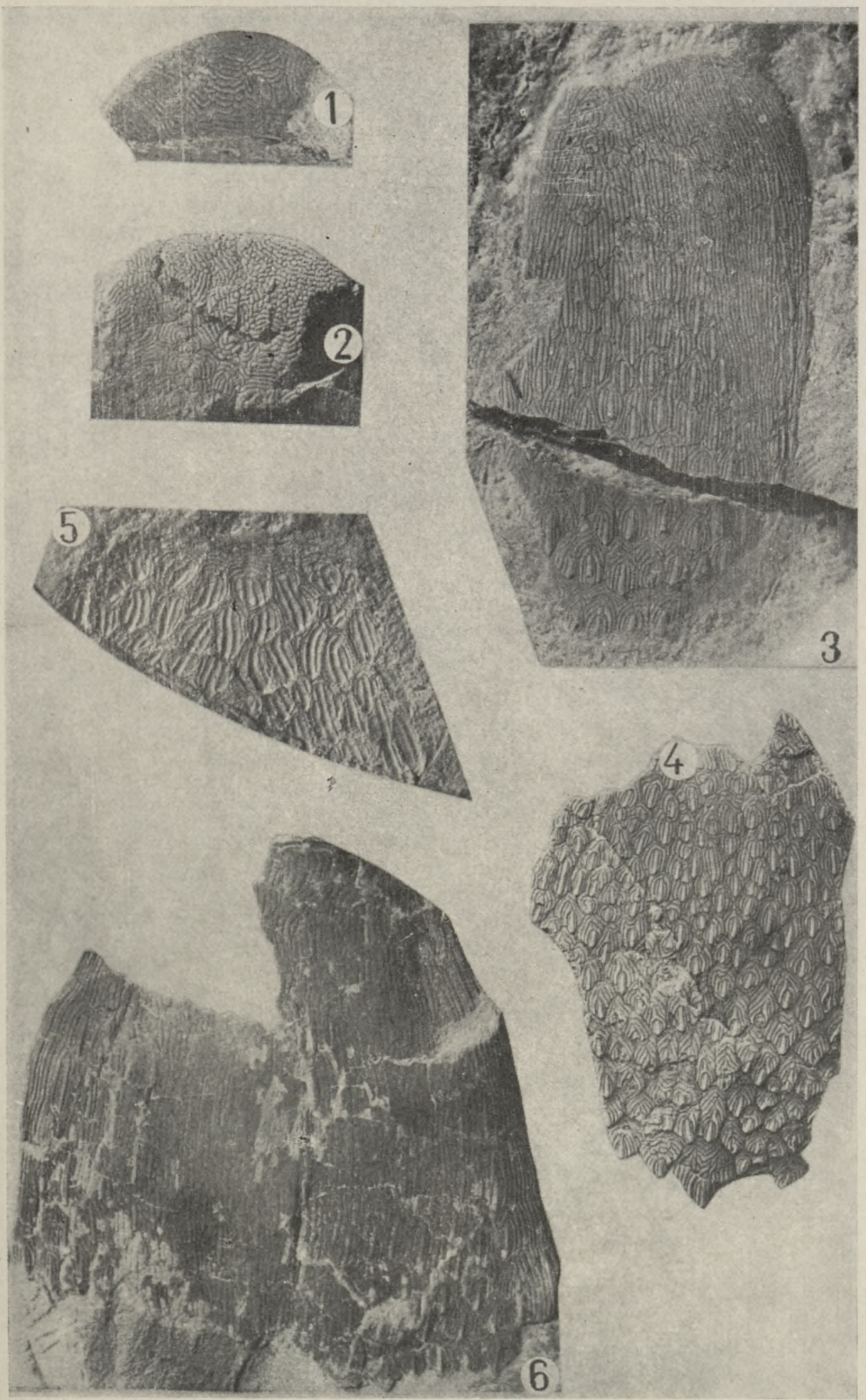

Text to plate see p. 67. 



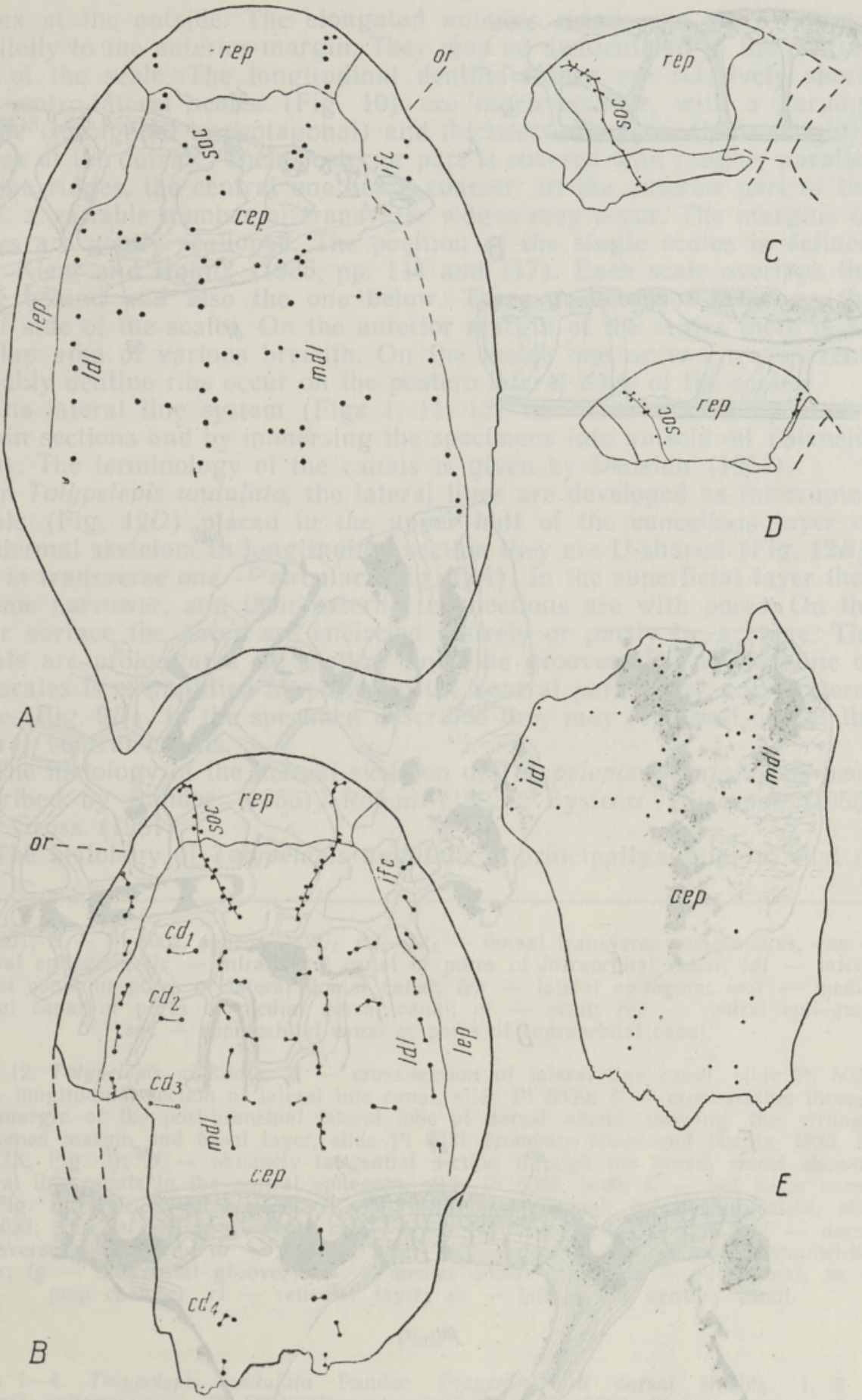

Fig. 11. Tolypelepis undulata, canals and pores of lateral line system and epitega of dorsal shield. $A$ - after Rohon (1893, Pl. I, Fig. 45) and Stensiö (1958, Fig. 169 B); $B$ - after Stensiö (1958, Fig. 215); $C-\operatorname{Pi} 5000 ; D-$ (Follows on p. 67.) 


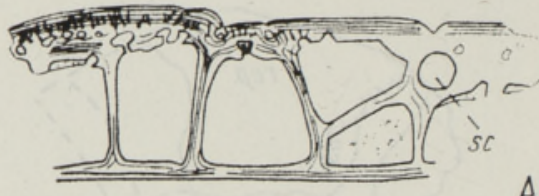

SC

B

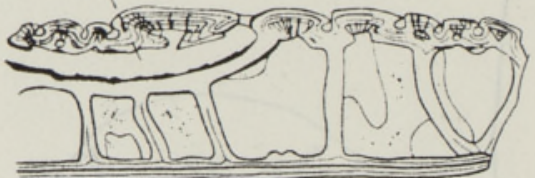

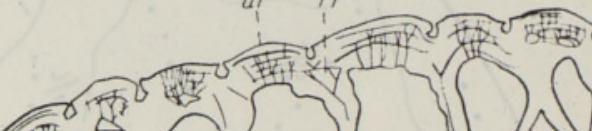
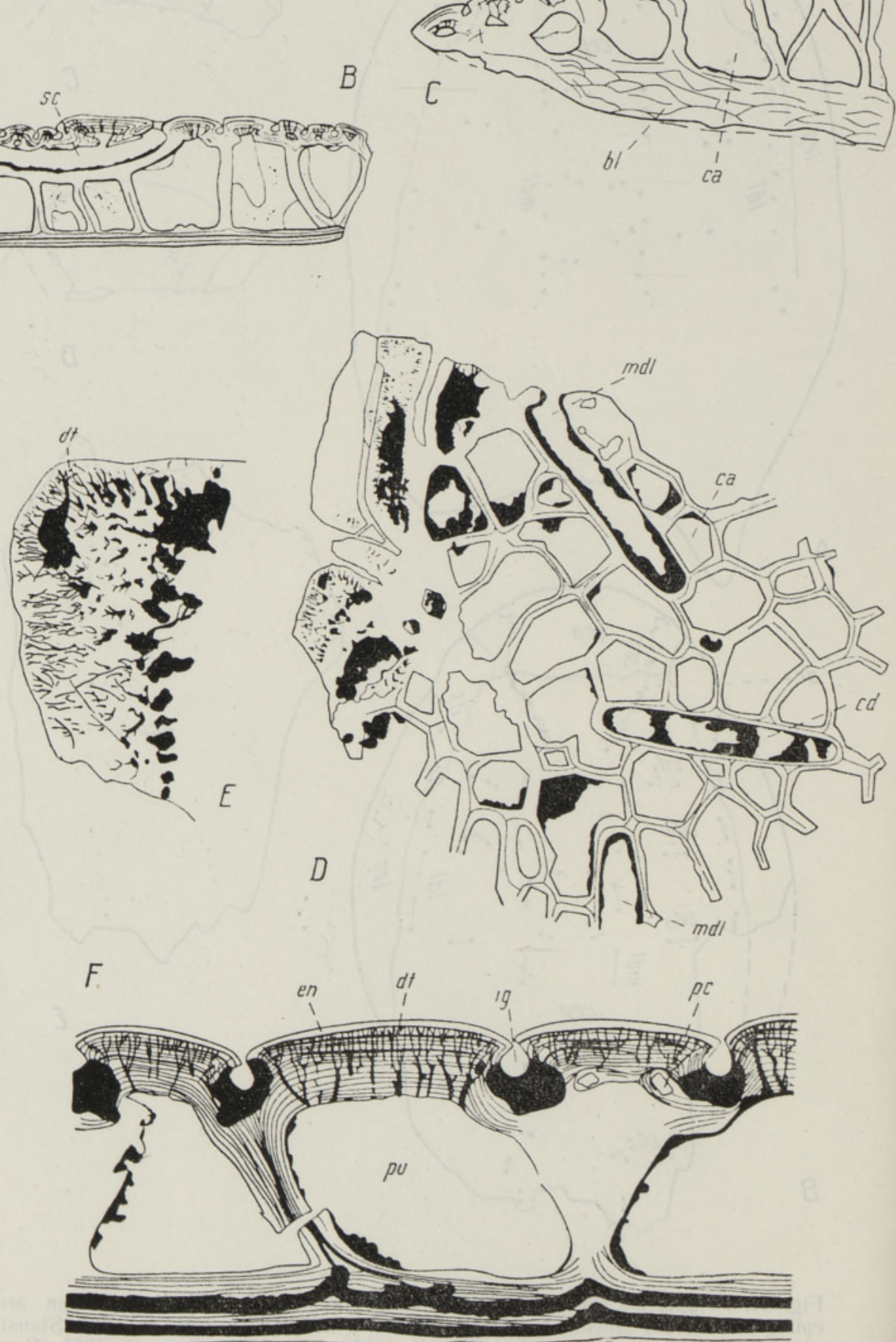

Fig. 12. 
convex at the outside. The elongated anterior ridges run more or less parallelly to the anterior margin. They may be denticulated in the central part of the scale. The longitudinal dentine ridges are relatively short. The ventro-lateral scales (Fig. 10) are much smaller, with a varying outline (tetragonal to pentagonal) and thickness. They are flat or slightly convex at the outside. Their posterior part is covered with roughly parallel dentine ridges, the central one being coarser. In the anterior part of the scale, a variable number of transverse ridges may occur. The margins of ridges are gently scalloped. The position of the single scales is defined after Kiaer and Heintz (1935, pp. 114 and 117). Each scale overlaps the scale behind and also the one below. There are contact faces on the inner side of the scales. On the anterior margin of the scales there is an overlap area of various breadth. On the inside one or two transparent, probably dentine ribs occur on the postero-lateral edge of the scales.

The lateral line system (Figs $1,11,12$ ) has been studied by means of thin sections and by immersing the specimens into aniscid oil (Stensiö, 1958). The terminology of the canals is given by Dension (1964).

In Tolypelepis undulata, the lateral lines are developed as interrupted canals (Fig. 12D) placed in the upper half of the cancellous layer of the dermal skeleton. In longitudinal section they are U-shaped (Fig. 12B), and in transverse one - circular (Fig. 12A). In the superficial layer they become narrower, and their external connections are with pores. On the outer surface the pores are encircled entirely or partly by a ridge. The canals are prolongated by shallow and fine grooves. The lateral line of the scales is exemplified by pores on the ventral part of the dorso-lateral scale (Fig. 9D). In the specimen described they may represent one of the lateral ventral canals.

The histology of the dermal skeleton of Tolypelepis undulata has been described by Pander (1856), Rohon (1893), Bystrow (Быстров, 1955) and Gross (1961).

The histology of Tolypelepis undulata is principally similar to that of

Pi 5001; $E-$ Pi 5002, approx. $\times 2^{1 / 2} . c d_{1}-c d_{4}$ - dorsal transverse commissures; cep central epitegum; $i f c$ - infraorbital canal or pores of infraorbital canal; $l d l$ - lateral dorsal canal or pores of lateral dorsal canal; lep - lateral epitegum; mdl - medial dorsal canal or pores of medial dorsal canal; or - orbit; rep - rostral epitegum; soc - supraorbital canal or pores of supraorbital canal.

Fig. 12. Tolypelepis undulata. A - cross-section of lateral line canal, slide Pi 5029; $B$ - longitudinal section of lateral line canal, slide Pi 5030; $C$ - cross-section through the margin of the post-branchial lateral lobe of dorsal shield showing the strongly thickened margin and basal layer, slide Pi 5031 (compare Kiaer and Heintz, 1935, PI. XXXIX, Fig. 3); $D$ - obliquely tangential section through the dorsal shield showing lateral line canals in the central epitegum, slide $\mathrm{Pi} 5032, \times 30 ; E$ - left lower corner of Fig. $D$, slide $\mathrm{Pi} 5032, \times 60 ; F-$ cross-section through the dorsal shield, slide Pi $5033 ; \times 60 . b l$ - basal layer; $c a$ - chamber of cancellous layer; $c d$ - dorsal transverse commissure; $d r$ - dentine ridge; $d t$ - dentine tubules; en - enamel-like layer; ig - intercostal groove; mdl - medial dorsal canal; $p c-$ pulp canal; $p u-$ pulp chamber; $r l$ - reticular layer; $s c$ - lateral line sensory canal.

\section{Plate}

Figs 1-4. Tolypelepis undulata Pander. Fragments of dorsal shields: 1, 2 rostral epitega; 1 - Pi 5001, Ohesaare Cliff; 2 - Pi 5000, Ruhnu boring, depth $176.2 \mathrm{~m} ; 3$ - central and lateral epitega, Pi 5003, Ohesaare Cliff; 4 - central epitegum, Pi 5002, Ruhnu boring, depth $176.1 \mathrm{~m}, \times 3$.

Figs 5-6. Tolypelepis undulata Pander. Incomplete ventral shields: 5 - anterior part of shield, 25-023, Butkunai boring (Lithuania), depth $401.8 \mathrm{~mm}, \times 4 ; 6-$ anterior . and medial part of shield, Pi 5004, Ruhnu boring, depth $176.1 \mathrm{~m}, \times 3$. 
other cyathaspids. The superficial layer of Tolypelepis undulata consists of dentine ridges, separated by intercostal grooves. In cross-section the grooves are subcircular. The crests of ridges are rounded and covered with a thin enamel-like layer (Fig. $12 F$ ). The chambers of the cancellous layer (pulp chambers) may be wide or relatively narrow. The chambers and ridges do not correspond in their position. From the pulp chamber and canal, dentine tubules run toward the surface of the ridge. The tubules are somewhat irregular, and branch once or more times (Fig. 12E, F). There seems to be a thin reticular layer (Fig. 12C) below the superficial one. It is composed of aspidine. The intercostal grooves and chambers of cancellous layer are surrounded by lamellar aspidine (cf. Denison, 1964, Figs 100-102). The basal layer, which also consists of aspidine lamellae, varies from a very thin (Fig. $12 A, B$ ) to a very thick (Fig. 12C) one.

Discussion. Genus Tolypelepis, the only representative of the subfamily Tolypelepidinae, is most similar to the members of the subfamily Cyathaspidinae. Its epitega are distinct, the ridge pattern is slightly elliptical on the central epitegum and transverse on the rostral one. In the coexistence of fine and coarser dentine ridges it resembles Ptomaspis, Cyathaspis and some Archegonaspis species. In other representatives of Cyathaspidinae the ridges are of uniform size. The dorsal shield of Tolypelepis is short $(32-38 \mathrm{~mm})$, in Listraspis and in some Vernonaspis species it is still shorter $(26-32 \mathrm{~mm})$. In other representatives of Cyathaspidinae the shield is much longer. The postrostral field is developed in Tolypelepis, Ptomaspis, Archegonaspis and Seretaspis; the pineal tessera occurs in the first three forms and in Cyathaspis. The median rostral process is absent in Tolypelepis, and that is also the case with Ptomaspis, Archegonaspis and Pionaspis. In the width ratio $(0.67-0.70)$ Tolypelepis resembles some Cyathaspis species (in C. banksi 0.70, after Kiaer, 1932, Pl. VIII, Fig. 2), in the orbital $(0.14-0.18)$ and pineal ratio $(0.24-0.25)$ it resembles Ptomaspis (in P. canadensis respectively 0.13 and 0.23 , by Denison, 1964, Fig. 108) and Archegonaspis (0.15-0.19 and $0.22-0.31)$.

\section{REFERENCES}

Denison R. H. 1964. The Cyathaspididae. A Family of Silurian and Devonian jawless vertebrates. Fieldiana, Geol., 13, No. 5.

Gross W. 1961. Aufbau des Panzers obersilurischer Heterostraci und Osteostraci Norddeutschlands (Geschiebe) und Oesels. Acta Zool., 42.

Heintz A. 1962. Les organes olfactifs des Heterostraci. Probl. act. Paleont. (Evol. Vertebr.), No. 104.

K i a e r J. 1932. The Downtonian and Devonian vertebrates of Spitsbergen. IV. Suborder Cyathaspida. Skr. Svalbard Ishavet, 52.

Kiaer J., Heintz A. 1935. The Downtonian and Devonian vertebrates of Spitsbergen. V. Suborder Cyathaspida. Part I. Skr. Svalbard Ishavet, 40.

$\mathrm{P}$ a nder C. H. 1856. Monographie der fossilen Fische des silurischen Systems der russisch-baltischen Gouvernements. St.-Petersburg.

Rohon J. V. 1893. Die obersilurischen Fische von Oesel. II Theil. Selachii, Dipnoi, Ganoidei, Pteraspidae und Cephalaspidae. Mém. Acad. Sci. St.-Petersb., S. 7, 41 , Nr. 5.

Stensiö E. A. 1958. Les cyclostomes fossiles ou ostracodermes. In Grassé P.-P., Traité de Zool., 13, fasc. 1.

Stensiö E. A. 1964. Les cyclostomes fossiles ou ostracodermes. In: J. Piveteau, Traité de Paléontologie 4, 1.

Б ы с тр о в А. П. 1955. Микроструктура панциря бесчелюстных позвоночных силура и девона. В сб.: Памяти акад. Л. С. Берга. Сб. работ по геогр. и биол. М.-Л. 
Tiiu MARSS

\section{BALTIKUMI ULEMSILURI TSUATASPIIDI TOLYPELEPIS EHITUS}

Vanimasse tsüataspiidide perekonda Tolypelepis kuuluvast liigist $T$. undulata tunti seni dorsaalkilpi ja mōnda fragmenti. Käesolevas artiklis kirjeldatakse $T$. undulata ventraal-, branhiaal-, lateraal(?)- ja suborbitaalplaati ning soomuseid. $T$. undulata elas hilissiluris (Eestis leidub tema jäänuseid alates kaugatuma lademe äigu kihtidest). Leiud pakuvad huvi nimetatud liigi morfoloogia ja liigisisese varieeruvuse seisukohast.

Тийу МЯРСС

\section{СТРОЕНИЕ TOLYPELEPIS ИЗ ВЕРХНЕГО СИЛУРА ПРИБАЛТИКИ}

Новые находки одного из самых древних циатаспидов Tolypelepis undulata (в Эстонии начиная с эйгуских слоев каугатумаского горизонта) дополняют материал, описанный Пандером (Pander, 1856), Рогоном (Rohon, 1893), Киером (Kiaer, 1932), Быстровым (1955), Гроссом (Gross, 1961) и Стеншё (Stensiö, 1958, 1964). В статье дается описание дорсальной, вентральной, бранхиальной, суборбитальной, латераль ной (?) пластинок и некоторых чешуй данного вида. Новый материал представляег интерес с точки зрения морфологии и индивидуальной изменчивости $T$. undulata. 